\title{
Locating the Position of Environmental Education in the South African School Curriculum: The Case of Grade R
}

\author{
Headman Hebe ${ }^{1 *}$ \\ ${ }^{1}$ University of South Africa, Pretoria, SOUTH AFRICA
}

Received 14 November 2018 - Revised 27 February 2019 - Accepted 17 March 2019

\begin{abstract}
The South African Curriculum and Assessment Policy Statement (CAPS) advocates for the integration of Environmental Education (EE) in all grades and subjects. The purpose of this study was to conduct a review of CAPS documents that guide pedagogy in all three subjects offered in Grade R, namely; English (Home Language), Life Skills and Mathematics. This was done to determine whether an alignment exists between the South African school curriculum aims and the curriculum content to enable the implementation of EE as espoused in CAPS. Informed by literature, the researcher singles out the "failure" of the CAPS documents to pinpoint the topics that could be used to facilitate the implementation of EE to focus his investigation. He uses an interpretivist qualitative approach to direct this inquiry. Through the application of content analysis and the deductive, inductive and abductive modes of inference, he examines the CAPS documents used to guide pedagogy in Grade R to identify the topics that could be used to facilitate the implementation of EE. The findings suggest that the CAPS documents contain various topics that could enable the implementation of EE. These findings hold positive implications for the teaching of EE both in South Africa and elsewhere, globally.
\end{abstract}

Keywords: abduction, curriculum and assessment policy statement (CAPS), environmental education $(E E)$, grade $R$, recontextualisation

\section{INTRODUCTION}

Owing to pervasive environmental crises, many education systems across the globe have, over the years, increasingly embraced the importance of curriculum reorientation to accommodate environmental education (EE) with the view to offset the upward trajectory of environmental crises (Fien, 2001; Ko \&Lee, 2003). In South Africa, the advent of democracy heralded the onset of gradual but notable public school curriculum reforms. From the introduction of Curriculum 2005 in 1997 to the current Curriculum and Assessment Policy Statement (CAPS), which came into being in 2011, the national Department of Education (DBE) has expressed its wish to have EE accommodated in South African classrooms across the spectrum, commencing in Grade R (known as the Preschool Class or Kindergarten elsewhere) to Grade 12.

Various key principles and aims of the CAPS point to the desire of the DBE to have EE taught in South African public schools. For example, the following is one of the ideals which express the wish of the DBE; "the National Curriculum Statement Grades R - 12 is based on the following principles .... Human rights, inclusivity, environmental and social justice: infusing the principles and practices of social and environmental justice and human rights as defined in the Constitution of the Republic of South Africa" (DBE, 2011a, p. 4). Likewise, the aim of the CAPS (Grade R - 12) which reads; "...to produce learners that are able to use science and technology effectively and critically showing responsibility towards the environment and the health of others" (DBE, 2011c, p. 5) also illustrates the commitment of the DBE towards EE.

(C) 2019 by the authors; licensee Modestum Ltd., UK. This article is an open access article distributed under the terms and conditions of the Creative Commons Attribution License (http://creativecommons.org/licenses/by/4.0/). 凶hebehn@unisa.ac.za herbzhn@yahoo.com (*Correspondence) 


\section{Contribution of this paper to the literature}

- Even though numerous studies have been conducted, which pinpoint impediments to the implementation of Environmental Education (EE), very few make a contribution towards addressing these barriers.

- More importantly, there is a dearth of literature that focuses on the analysis/synthesis of school curriculum with the aim of identifying topics that could facilitate the implementation of EE.

- This study demonstrates that, through the use of innovative theoretical frameworks, school curricula can be analysed and topics identified, which could be used to enable EE implementation at school level across various grades and subjects.

Despite the expressed wishes of the DBE, the implementation of EE in South Africa, just like in many parts of the world, has been beset with an array of impediments. Accordingly, this inquiry seeks to contribute towards addressing some of those barriers.

\section{LITERATURE REVIEW}

\section{Impediments to the Implementation of Environmental Education}

In order to contextualise the problem, the rationale and the aim of this study; it is essential to commence by providing a brief background of the study which focuses on the hindrances to the implementation of EE. Empirical evidence based on studies conducted in numerous countries, globally, suggests that many impediments to the implementation of EE "transcend place and time" (Evans, Whitehouse, \& Gooch, 2012, p. 135). This is discernible from the fact that the barriers identified by Ham and Sewing (1988) and preceding studies continue to persist in recent times. These barriers to the implementation of EE include what Ham and Sewing (1988) defined, broadly, as: conceptual barriers (e.g. misconceptions about EE and who should teach it), logistical barriers (e.g. perceived lack of time, funding and resources), educational barriers (e.g. lack of training in the implementation of EE), and attitudinal barriers (i.e. the attitudes that teachers hold towards the teaching of EE).

Literature suggests that many teachers lack knowledge of the concept of EE and related issues (Green \& Somerville, 2015; Ralph \& Stubbs, 2014). This is accentuated by Schudel, Le Roux, Lotz-Sisitka, Loubser, O'Donoghue and Shallcross (2008) whose study, conducted on South African in-service teachers, noted that they "had but a rudimentary understanding of EE" (p. 552). These sentiments were echoed by Mwendwa (2017) whose study, which involved teachers in Tanzania, found that "inadequate knowledge of environmental education was the common challenge" (p. 10) to the integration of EE in the classroom.

Research also suggests that the implementation of EE is hampered by multitudes of logistical constrains. Inadequate or lack of Teaching and Learning Support Material (LTSM) is viewed as one of the logistical hindrances to EE implementation (Ketlhoilwe, 2003; Maharajh, Nkosi, \& Mkhize, 2016). Various studies also noted the shortage of funds, teachers' lack of time to teach EE and huge classroom sizes (Ko \& Lee, 2003; Maharajh et al., 2016; Ralph \& Stubbs, 2014) as deterrents to the implementation of EE.

In respect of educational barriers to EE implementation, Ko and Lee (2003) identified the lack of teacher inservice training as one among numerous hindrances. Likewise, Maharajh et al. (2016) identified inadequate training of both teachers and curriculum advisors as one of the impediments to EE. This observation is echoed by Mathenjwa (2014) who decries the dearth of "properly trained environmental education specialists to implement it effectively in schools" (p. 3).

Literature also identified attitudinal barriers to EE implementation. The notion that EE is a burden that should be implemented only during the teaching of selected subjects (Ketlhoilwe, 2003; Lane, 2006; Maharajh et al., 2016; Ralph \& Stubbs, 2014) seems the most pervasive attitudinal barrier. Subjects such as natural sciences and geography have been identified as some of the few subjects that should be used to facilitate EE. Writing to amplify this flawed pedagogical approach to EE, Fien (2001) argues that for a long time "environmental education had been seen as a prerogative of subjects such as science and geography" (p.7). Accordingly, he advocates for the reorientation of global education systems so as to do away with the compartmentalisation of EE "into separate, exclusive subject areas" (Fien, 2001, p. 15).

\section{STATEMENT OF THE PROBLEM AND PURPOSE OF THE STUDY}

Fien (2001), as cited above, argues that EE has been implemented in the teaching of selected subjects. This erroneous approach to EE is, partly, the reason behind this research inquiry. In the main, this investigation was evoked by Mokhele's (2011) observation that in South Africa there is no educational framework that guides teachers on what to teach "as part of integrating environmental learning in the different subjects" (p.81). Mokhele argues 
that as a consequence of this shortcoming, teachers face "real uncertainty about what to include and what not to include in their lessons" (ibid.) as part of EE. Hence, Motshegoa (2006) amplifies this point by writing that in South Africa EE "policy practice or interpretation and implementation is the prerogative of teachers" (p. 12). Indeed, as Fien (2001) points out, this shortcoming is not unique to South Africa.

Literature suggests that in numerous countries, e.g. Australia, the United States of America, Canada, New Zealand, and so on; the what (pedagogical content) and how (pedagogical strategies) of EE implementation are the prerogative of schools and individual teachers (Binstock, 2006; Connell, Shearer, \& Tobin, 2006; Fien, 2001; Stokes, Edge, \& West, 2001). For example, the early years' curriculum guidelines of Queensland, Australia, allow for individual teachers to "select, modify and create" (Connell, et al., 2006, p. 45) their own individual "examples of learning experience" (ibid.). This invariably leaves room for individual teachers to decide whether or not to implement EE in their lessons. In a study which "covered all 15 member states of the European Union" (Stokes et al., 2001, p. 5), the researchers found that in 18 out of 19 states/regions studied, individual teachers had the liberty to decide what and how to implement EE in their classrooms.

Mokhele (2011), posits that the approach wherein teachers decide on the what and how of EE implementation "is a potentially empowering opportunity for the teachers" (p. 81). However, in the same vein, Mokhele (2011) also argues that this approach "is also fraught with dangers" (ibid.). This view by Mokhele (2011), partly, derives from the teachers' lack of knowledge regarding the concept of EE and, the concomitant uncertainty concerning the what and the how of EE implementation. Hence, based on these notable shortcomings on the part of the teachers, it could be argued that the absence of frameworks (in the school curriculum) on EE implementation "could also mean a complete marginalisation of any environmental education content in some subject areas" (Mokhele, 2011, p. 81).

The literature perused in preparation for this inquiry suggests that there is paucity of research that seeks to provide guidance regarding the what and how of EE implementation across different grades at school level. Accordingly, this research seeks to contribute towards filling this void in literature and to "provide some guidance to teachers for the future development of environmental education" (Ko \& Lee, 2003, p. 188). This should, arguably, also help to make teachers "effective in empowering young people to dedicate their lives to sustaining their, and our own future" (Fien, 2001, p. 8). To this end, this inquiry attempts to respond to the question:

Which topics in the South African CAPS (Grade R) could be used to enable the implementation of EE?

\section{THEORETICAL FRAMEWORK}

This study draws upon the work of several authors. For example, Bernstein's (2003a; 2003b; 1999) views on pedagogical practice and recontextualizing principle provided tools for the 'selection' of topics that could be used to teach EE. Equally, McBride, Brewer, Berkowitz and Borrie (2013) provided insight on frameworks for environmental literacy. Likewise, the seminal work of Lucas (1972) helped with perspectives on strategies for the integration of EE in pedagogy.

The principle of recontextualisation as used by Bernstein (2003b) is important in this study, hence a brief discussion of this concept is necessary. Nsubuga (2008) provides an insightful reflection on how Bernstein's notion of recontextualisation should be conceived. She writes that, "Bernstein defined recontextualisation as the process by which educational knowledge is transferred from one educational site to another" (p. 101). Recontextualisation is susceptible to philosophical dictates and interests of those with the power to recontextualise; hence Nsubuga (2008) argues that recontextualisation "is subject to differing ideologies, interests and contexts of agents and agencies" (p. 101). Furthermore, to amplify the role of power distribution and control in pedagogical practice, wherein recontextualisation is located, Nsubuga (2008) asserts that "whoever controls the pedagogic device gets to determine not only the contents of what is transferred (i.e. curriculum content), but also the methods by which it is transferred (i.e. theory of instruction) and evaluated (i.e. the assessment of systems)" (p. 101).

As an inherent element of pedagogical practice, recontextualisation conforms to modalities and rules that direct pedagogical practice. One set of rules of relevance to this inquiry is what Bernstein (2003b) refers to as criteria rules. Criteria rules can be either "explicit and specific" (Bernstein 2003b, p. 201) or "implicit, multiple and diffuse" (ibid.). Also, these rules apply to, inter alia, visible pedagogy (which puts emphasis on learner performance) and invisible pedagogy (whose focus is on processes and procedures of knowledge acquisition). Of significance to this research is that, within the ambit of invisible pedagogy, recontextualisation helps those in the realm of pedagogical practice with "both the selection and organisation of what is to be acquired" (Bernstein, 2003b, p. 202) or, put differently, it helps them "to create and systematize the contents to be acquired and the context in which it is to be acquired" (ibid.). Therefore, since recontextualisation is, by design, predicated on criteria rules, which are determined by the recontextualiser (the person who applies the process of recontextualisation in pedagogy); the recontextualiser can be said to possess the power to decide on the "'how' and the 'what' of the practice" (Bernstein, 2003b, p. 196).

As stated earlier, this investigation sought to address deficiencies in pedagogy in that it attempted to identify both 'explicit' and 'implicit' topics in the CAPS that could help facilitate EE. Therefore, guided by Bernstein's 
(2003b) views on pedagogical practice, the researcher used recontextualisation in order to contribute towards facilitating knowledge acquisition. This was propelled, particularly, by Bernstein's (2003b, p.201) assertion that "pedagogy works by making available to the child what is missing in the product". Therefore, in this inquiry, the researcher used recontextualisation with the view to contribute towards providing the teacher and the learner with what is missing in the product called the CAPS.

However, notwithstanding the fact that, as the preceding points suggest, recontextualisation is subject to the power, interest, dictates and etcetera of the recontextualiser; recontextualisation is also made possible by what could be termed the expert knowledge of the recontextualiser. Therefore, it is the contention of this researcher that the expert knowledge of the recontextualiser also influences the what (content) and the how (process) of recontextualisation. This form of knowledge is acquired gradually, in various ways and through interaction with different texts and, it manifests as both "non-school everyday knowledge... and the educational knowledge" (Bernstein, 2003a, p. 159). Through expert knowledge "anyone individual may build up an extensive repertoire of strategies which can be varied according to the contingencies of the context" (Bernstein, 1999, p. 161) within which pedagogical practice occurs so as to facilitate curriculum recontextualisation.

This research is also informed by McBride, Brewer, Berkowitz and Borrie's (2013) discussion on frameworks for environmental literacy. Since the goal of EE is, essentially, to advance environmental literacy (EL), EE and EL are innately interwoven (Eilam \& Trop, 2012; Norris, 2016; Roth, 1992). Therefore, this discussion on frameworks for environmental literacy helped focus this study, especially, its research design.

The EL frameworks discussed by McBride et al. (2013) were deemed relevant to this research because they "exhibit a high degree of similarity and congruence with respect to their major components" (McBride et al., 2013, p. 6). Additionally, since these frameworks also highlight the content elements that should form part of an EEinclined programme, they helped this researcher in the identification of curriculum topics that could enable the implementation of EE. Accordingly, McBride et al. (2013) write that, "all frameworks include knowledge of basic ecological concepts, environmental sensitivity or appreciation, awareness of environmental issues and problems, and skills and behaviours to prevent and/or resolve these issues as key attributes of the environmentally literate individuals" (p. 6). Thus, in this research, the inquirer took the preceding points into consideration in the identification of the topics that could be used to facilitate the implementation of EE.

Furthermore, the frameworks provide some key characteristics that define an environmentally literate citizen and, also underscore certain elements that should be developed through EE-inclined programmes. To accentuate this point, McBride et al., (2013) write that, "as reflected in all the frameworks, an environmentally literate citizen is an individual who is, most importantly, informed about environmental issues and problems and possess the attitudes and skills for solving problems" (p. 7). The frameworks discussed by McBride et al. (2013) also highlight various domains that need to be developed in order to advance EL. These areas include: affective (social and emotional) domain, cognitive skills (for addressing environmental problems), physical (fine-motor and grossmotor) skills, knowledge (about the environment and its systems), communication skills, pro-environment attitudes and values (Erdoğan, Bahar, Özel, Erdaş, \& Uşak, 2012; Gordon \& Browne, 2011; Srbinovski, Erdoğan, \& Ismaila, 2010). These domains need to be developed from the stage of early childhood (Gordon \& Browne, 2011). As indicated in the results of this inquiry (cf. Tables 1, 2 and 3), the domains that could be developed through EE are highlighted. Hence, without a doubt, the EL frameworks referred to by McBride et al. (2013) helped in shaping this research.

The seminal work by Lucas (1972) also shaped the direction of this inquiry. Lucas (1972) contributed to the genesis of the triadic approach to environmentally-inclined pedagogy, i.e. education about, in and for the environment; a strategy which has since become a mantra for many in the field of EE. Education about the environment focuses on the teaching and learning of facts, concepts, patterns and systems that exist in the environment and how they function and relate to one another, and the role of human beings in the environment (Kopelke, 2012; Le Grange, 2002). Education in the environment takes place outdoors and gives attention to processes and activities that enable the learners to acquire awareness, values, knowledge, skills and development of attitudes that equip them to play a constructive role in addressing environmental problems (Kopelke, 2012). This is done in the environment and through direct interaction with the environment (Lucas, 1972). Education for the environment is a practical culmination of and is more involved than education about and in the environment. It seeks to enable the learner to demonstrate civic responsibility through the application of knowledge and skills by embarking on environmental action in order to enforce social change. Education for the environment enjoins the learner to actively contribute towards the provision of lasting solution to environmental challenges.

\section{RESEARCH METHOD AND DESIGN}

In this inquiry an interpretivist qualitative approach was used to identify topics, in the CAPS, that could be used to enable the implementation of EE in Grade R classrooms. This approach was chosen because it helps an 
inquirer to conduct a "more flexible type of research where the process of discovery is blended with intuition" (Daymon \& Holloway, 2011) and, is appropriate for investigations where there is little or no previous research (Creswell, 1994). Additionally, this perspective allows the researcher to use personal subjective experiences as important sources of information (Daymon \& Holloway, 2011).

\section{Data Collection and Analysis}

The researcher retrieved and painstakingly read and re-read each of the three CAPS documents used to guide pedagogical processes in all three subjects taught in Grade R, namely; Mathematics, Life Sciences and English Home Language (Department of Basic Education, 2011a; 2011b \& 2011c). The reading of these documents was meant to help the researcher obtain an overall picture of the contents and, thereafter, to conduct an in-depth content analysis. His focus was on all the topics that have to be covered, pedagogically, in a typical academic year. During the reading and analysis of the documents, the researcher also looked for any suggestions or hints regarding the teaching strategies that could be used in the teaching of respective topics and the domains that could be developed in the child during the process of learning and teaching.

The analysis of the CAPS documents was facilitated through the use of the theoretical framework outlined earlier in this paper and, three modes of inference, namely; deduction, induction and abduction. These modes of inference were deemed relevant because as Yu (2005) asserts, "abduction, deduction and induction work (best) together to explore, refine and substantiate research questions" (p. 3) - [insertion and emphasis by the researcher]. In using these three modes of reasoning, the researcher was mindful of the strengths and weaknesses of each mode. Since this research sought to go beyond the explicit, the three modes had to complement one another. Therefore, in order to 'uncover' the implicit, it was necessary to use deductive reasoning, which relies solely on available evidence (Lassiter \& Goodman, 2017), together with induction and abduction, the modes that facilitate knowledge discovery (Svenning, 2001).

The selection of a topic such as Animals: birds, dinosaurs and reptiles (refer to Table 2) as a potential enabler of environmentally-inclined pedagogy in Life Skills emanates from the use of premises and conclusions as applicable to deductive reasoning (Cottrell \& McKenzie, 2005). In order to select this topic, the researcher commenced by acknowledging that ecology is the study of relationships which living organisms have with one another and with the non-living environment (Anand, Gonzalez, Guichard, Kolasa, \& Parrott, 2010). Thereafter, he reasoned that since the EL frameworks (McBride et al., 2013) accentuate ecology as a potential enabler of EE, then a topic on Animals can be used to facilitate EE in Grade R.

In instances where deductive reasoning was inapplicable, inductive and abductive modes of reasoning were used to aid the analysis of the documents. Unlike deductive reasoning, inductive reasoning is not predicated on premises that support one another to enable an individual to draw plausible conclusions. Inductive reasoning relies on the use of recurring patterns as sources of "empirical evidence...that something actually is operative" (Yu, 2005, p. 3). Additionally, "in inductive reasoning, the thinking and procedures are more free flowing and less defined than in deductive reasoning" (Cottrell \& McKenzie, 2005, p. 4). Therefore, in order to determine whether certain topics covered in the Grade R CAPS documents could be used to facilitate EE, the researcher relied mostly on patterns from classroom-based observations. For example, during numerous Grade R classroom observations (the observations conducted by the researcher as part of his $\mathrm{PhD}$ programme recently), the researcher noted that the topic on weather is often used to teach EE.

Abduction, the mode referred to as "inference to the best explanation" (Ovchinnikova, Gordon \& Hobbs, 2013, p. 42) was used on all occasions where neither deductive reasoning nor inductive reasoning could be applied. As a recontextualisation-friendly mode, abduction enables the researcher to identify "connections and relations that are not obvious" (Songqwaru, 2012, p. 54). Furthermore, abduction permits researchers to use their "additional knowledge about the world" (Ovchinnikova, Gordon, \& Hobbs, 2013, p. 42) to provide an explain about various phenomena (Sappleton, 2013; Yu, 2005). Therefore, the researcher relied mainly on his knowledge of environmental issues, his pedagogical interests and the power to recontextualise to 'abduct' numerous topics as possible enablers of EE. Abduction was applied in all three Grade R subjects. For example, topics such as news (Home Language) summer (Life Skills) and money (Mathematics) were identified through abduction.

\section{TRUSTWORTHINESS}

In this inquiry, the researcher was guided by Potter and Levine-Donnerstein (1999) who assert that in content analysis, validity can be ensured through faithfulness to the theory that guides coding. Accordingly, the researcher ensured that the selection of topics that could be used to enable the implementation of EE was guided by the theoretical framework developed for this study (Krippendorff, 1980) as discussed earlier in this paper. Additionally, two independent scholars with expert knowledge in both EE and curriculum issues were requested 
to proffer their opinions on the 'appropriateness' and relevance of the topics selected as potential enablers of EE implementation in the grade selected for this study.

\section{RESULTS}

In this section the results are presented followed by a brief discussion of the findings. Three tables are used for this purpose. Each of the tables depicts the outcome of the analysis of the CAPS documents. Table 1 indicates some of the topics in the English Home Language that could be used to enable the implementation of EE in Grade R while Tables 2 and 3, indicate selected topics that could be used to aid EE integration in Life Skills and Mathematics, respectively. The analysis in each of the tables focuses on three aspects, namely; the topics that could enable EE implementation, the pedagogical strategies that could be used to facilitate EE and the domains that could be developed in the teaching and learning of EE in Grade R.

In the first column of each table, the topic that was deemed a potential enabler of EE integration is presented. For example, according to Table 1, the topic on the weather chart could facilitate the presentation of EE in Grade R. The second column provides information on the pedagogical strategies, as postulated by Lucas (1972), that could be used to present a particular topic. For example, according to Table 1, the topic on the weather chart could be presented through the use of education about the environment. The third column serves to highlight the domains that could be developed in the learner during the integration of EE in the presentation of a specific topic. For example, according to Table 1, the integration of EE during the presentation of the topic on the weather chart could facilitate the development of the cognitive domain, among other spheres of development. Accordingly, the following tables depict the results of this inquiry.

Table 1. Some of the topics that could enable the implementation of EE in Grade R: English Home Language

\begin{tabular}{|c|c|c|}
\hline TOPIC & $\begin{array}{l}\text { EE APPROACH } \\
\text { (education about, in and for the environment) }\end{array}$ & CHILD DEVELOPMENT DOMAINS \\
\hline Weather Chart & $\begin{array}{l}\text { The learners could "talk about the day, date, the weather } \\
\text { chart...and any special events for the day" (DBE 2011a, p. 11). } \\
\text { Thus, education about the environment is feasible. }\end{array}$ & $\begin{array}{l}\text { Cognitive skills (e.g. knowledge acquisition } \\
\text { about weather processes and their impact on the } \\
\text { environment). }\end{array}$ \\
\hline News & $\begin{array}{l}\text { Learning about the environment feasible where "children share } \\
\text { their news, 'show and tell' about a picture or object, talk about } \\
\text { the diary, sports, concerts, topical events and story-telling" } \\
\text { (DBE 2011a, p.11). }\end{array}$ & $\begin{array}{l}\text { Cognitive skills (e.g., development of awareness } \\
\text { about their immediate environment and beyond), } \\
\text { Communication skills (linguistic development } \\
\text { facilitated through class talk), etc. }\end{array}$ \\
\hline $\begin{array}{l}\text { Outdoor free } \\
\text { play }\end{array}$ & $\begin{array}{l}\text { "Climbing on a wooden climbing frame or riding on the cycle } \\
\text { track ... opportunities for children to 'read' road signs" (DBE } \\
2011 \text { a, p. 20-21), could enable learning about the environment. }\end{array}$ & $\begin{array}{l}\text { Promote spatial awareness; Encourage } \\
\text { letter/word recognition. (DBE, 2011a). }\end{array}$ \\
\hline $\begin{array}{l}\text { Stories and } \\
\text { songs }\end{array}$ & $\begin{array}{l}\text { By "listening to and talking about stories and singing songs" } \\
\text { (DBE 2011a, p. 23), learners could learn about the environment. }\end{array}$ & $\begin{array}{l}\text { Development include; cognitive, physical, } \\
\text { emotional, linguistic, spatial awareness (e.g. } \\
\text { singing could involve dancing; story telling } \\
\text { involves imagination/thinking). }\end{array}$ \\
\hline $\begin{array}{l}\text { Pictures in } \\
\text { poster and } \\
\text { common objects } \\
\text { in pictures }\end{array}$ & $\begin{array}{l}\text { Talking about and "recognizing common objects in pictures" } \\
\text { (DBE 2011, pp. } 23 \text { and 26) could promote learning about the } \\
\text { environment. }\end{array}$ & $\begin{array}{l}\text { Cognitive development (e.g. talking about } \\
\text { various people, events and phenomena could } \\
\text { facilitate knowledge development). }\end{array}$ \\
\hline $\begin{array}{l}\text { Sound } \\
\text { recognition }\end{array}$ & $\begin{array}{l}\text { Learning about sounds of organisms and other phenomena in } \\
\text { the immediate environment and beyond (DBE, 2011a) is likely. }\end{array}$ & $\begin{array}{l}\text { Cognitive skills (e.g. thinking), Perceptual skills } \\
\text { (e.g. visual memory), } \\
\text { Affective development (some sounds evoke } \\
\text { emotional reaction). }\end{array}$ \\
\hline $\begin{array}{l}\text { Recognizing } \\
\text { own name }\end{array}$ & $\begin{array}{l}\text { Learning about self and 'others' could enable awareness in } \\
\text { learners about their respective positions in the environment. }\end{array}$ & $\begin{array}{l}\text { Cognitive skills (e.g. learners could develop } \\
\text { knowledge about themselves/others and their } \\
\text { positions in the environment and, the reciprocal } \\
\text { relationships in the environment. }\end{array}$ \\
\hline $\begin{array}{l}\text { Learner draws or } \\
\text { paints pictures }\end{array}$ & $\begin{array}{l}\text { Learners could draw or paint pictures "to convey a message" } \\
\text { (DBE, 2011a, p. 30) about their environment (e.g. what it looks } \\
\text { like and how it should look like). Also, learners could be allowed } \\
\text { to talk about how they feel about the environment and discuss } \\
\text { what they think could be done to solve environmental problems } \\
\text { - e.g. papers littered around the school yard. }\end{array}$ & $\begin{array}{l}\text { Areas of development include: cognitive skills, } \\
\text { emotional skills, etc. }\end{array}$ \\
\hline
\end{tabular}


Table 2. Some of the topics that could enable the implementation of EE in Grade R: Life Skills

\begin{tabular}{|c|c|}
\hline TOPIC & $\begin{array}{l}\text { EE APPROACH } \\
\text { (education about, in and for the environment) }\end{array}$ \\
\hline $\begin{array}{l}\text { Festivals and } \\
\text { special days }\end{array}$ & $\begin{array}{l}\text { A focus on "festivals and special days celebrated by the } \\
\text { community" (DBE 2011c, p.15) could promote learning about, in } \\
\text { and for the environment (e.g. through participation in local cultural } \\
\text { festivals and special days that promote environmental awareness } \\
\text { such as arbour day). }\end{array}$ \\
\hline $\begin{array}{l}\text { Me at school } \\
\text { and in the } \\
\text { classroom }\end{array}$ & $\begin{array}{l}\text { Learning about the self in relation to the environment. The learner } \\
\text { gets to know about the rules, roles, expectations, personal relations } \\
\text { regarding the self, and 'others' in the environment. Learning in and } \\
\text { for the environment feasible (e.g. keeping surroundings free from } \\
\text { pollution). }\end{array}$ \\
\hline $\begin{array}{l}\text { Summer (or } \\
\text { any other } \\
\text { season) }\end{array}$ & $\begin{array}{l}\text { Learning about, in and for the environment likely, e.g. learning } \\
\text { about the weather associated with the season, its effects on various } \\
\text { phenomena, etc. Also, learning of pro-environment action (e.g. } \\
\text { planting trees in spring to replenish vegetation) practicable. }\end{array}$ \\
\hline Safety & $\begin{array}{l}\text { Learning about safety at home, school and elsewhere (e.g. on the } \\
\text { road, safety from strangers, etc.). }\end{array}$ \\
\hline Transport & $\begin{array}{l}\text { Learners could talk(learn) about "transport long ago" (DBE 2011c, p. } \\
\text { 19, especially transport evolution and impact of transport on the } \\
\text { environment (e.g. accidents, pollution, etc.). }\end{array}$ \\
\hline
\end{tabular}

Jobs people do Learning about people and their activities in the environment.

\section{CHILD DEVELOPMENT DOMAINS}

Physical development (dancing in celebration of a specific festival in the learners' environment), social, personal, emotional and cognitive development also likely.

\begin{tabular}{|c|c|c|}
\hline & & $\begin{array}{l}\text { Emotional skills (some jobs evoke emotions in } \\
\text { people). }\end{array}$ \\
\hline Water & $\begin{array}{l}\text { Learning about, in and for the environment possible (e.g. sources } \\
\text { and uses/abuse of water; water pollution, activities on consumption } \\
\text { school, water conservation, etc.). }\end{array}$ & $\begin{array}{l}\text { Cognitive skills (e.g. investigating the uses of } \\
\text { water at school), Communication (talking about } \\
\text { water), etc. }\end{array}$ \\
\hline $\begin{array}{l}\text { Farming: } \\
\text { Dairy, wool, } \\
\text { fruit and } \\
\text { vegetable }\end{array}$ & $\begin{array}{l}\text { Learning about, in and for the environment possible: learning } \\
\text { about (the land as a source of various products, the importance of } \\
\text { water and soil in farming); in the environment (e.g. exploration of } \\
\text { the school garden) and for the environment (e.g. learning about } \\
\text { invasive vegetation and how to control it). }\end{array}$ & $\begin{array}{l}\text { Cognitive skills (e.g. recall of various dairy } \\
\text { products), } \\
\text { Language skills (communication about farm } \\
\text { products, their uses, etc.), etc. }\end{array}$ \\
\hline $\begin{array}{l}\text { hy } \\
\text { onment }\end{array}$ & $\begin{array}{l}\text { Various opportunities can be created. For example; Learning about } \\
\text { "the importance of a clean environment...ways in which people } \\
\text { pollute the environment...and the importance of recycling" (DBE, } \\
2011 c \text {, p. 20); Learning in the environment (e.g. observing ways in } \\
\text { which pollution affects the environment) and, taking action for the } \\
\text { environment (e.g. learners addressing pollution at school). }\end{array}$ & $\begin{array}{l}\text { Cognitive skills (e.g. thinking about solutions to } \\
\text { environmental problems); } \\
\text { Language skills (during verbal interaction), } \\
\text { Physical skills (fine-motor and gross-motor } \\
\text { skills), Positive attitudes and respect for the } \\
\text { environment, etc. }\end{array}$ \\
\hline $\begin{array}{l}\text { Animals: Birds, } \\
\text { Reptiles, } \\
\text { Dinosaurs and } \\
\text { other Wild } \\
\text { animals }\end{array}$ & $\begin{array}{l}\text { Learning about different types of animals, their habitats, etc.; (e.g., } \\
\text { learning about "general characteristics of a bird" DBE 2011c, p. 21). } \\
\text { Learning in the environment (e.g. in a game farm) about "how wild } \\
\text { animals live" (DBE 2011c, p. 21). Learning for the environment (e.g. } \\
\text { learners can "choose one animal to study" (DBE, 2011c, p. 21) such } \\
\text { as rhino and learn about it poaching and talk about possible ways } \\
\text { to prevent its extinction. }\end{array}$ & $\begin{array}{l}\text { Cognitive skills (investigation and observation } \\
\text { of animal behaviour), } \\
\text { Language skills (communication about } \\
\text { organisms), } \\
\text { Positive attitudes towards fauna, etc. }\end{array}$ \\
\hline $\begin{array}{l}\text { Dramatization, } \\
\text { Music and } \\
\text { Make-believe } \\
\end{array}$ & $\begin{array}{l}\text { Learning about personal environment through personal } \\
\text { experiences(e.g. dramatization and singing inspired by local events } \\
\text { and experiences). }\end{array}$ & $\begin{array}{l}\text { Cognitive skills (e.g. thinking about local events), } \\
\text { Language skills (e.g. talking about local events), } \\
\text { etc. }\end{array}$ \\
\hline $\begin{array}{l}\text { Sports and } \\
\text { Games }\end{array}$ & $\begin{array}{l}\text { Learning about ecological processes, roles and relationships in the } \\
\text { ecosystem and, the need for protection of biodiversity (e.g., by } \\
\text { exposing learners to games such as "buck and hunters; cat and } \\
\text { mouse; wolf and sheep; catch the tail, etc." (DBE, 2011c, p. 28). }\end{array}$ & $\begin{array}{l}\text { Inculcation of positive attitudes and values } \\
\text { towards various organisms, } \\
\text { Development of cognitive and communication } \\
\text { skills (e.g. thinking and talking about organisms). }\end{array}$ \\
\hline
\end{tabular}


Table 3. Some of the topics that could enable the implementation of EE in Grade R: Mathematics

\begin{tabular}{|c|c|c|}
\hline TOPIC & $\begin{array}{l}\text { EE APPROACH } \\
\text { (education bout, in and for the environment) }\end{array}$ & CHILD DEVELOPMENT DOMAINS \\
\hline $\begin{array}{l}\text { Space and } \\
\text { Shape } \\
\text { (Geometry) }\end{array}$ & $\begin{array}{l}\text { The purpose of the topic is to help "learners recognise and describe } \\
\text { shapes and objects in their environment that resemble } \\
\text { mathematical objects and shapes" (DBE, 2011, p. 10). Thus, learning } \\
\text { about diverse phenomena in the learners' surroundings is possible. }\end{array}$ & $\begin{array}{l}\text { Cognitive skills (e.g. spatial awareness), } \\
\text { Communication skills (e.g. learners could talk } \\
\text { about the shapes of phenomena in their } \\
\text { environment), etc. }\end{array}$ \\
\hline Money & $\begin{array}{l}\text { Learning about monetary units used in South Africa could enable } \\
\text { learners to know the value of natural resources, e.g. trees, in the } \\
\text { manufacturing of "paper money"; and the need to preserve these } \\
\text { resources. }\end{array}$ & $\begin{array}{l}\text { Cognitive skills (e.g. thinking about the origin of } \\
\text { money and its use), } \\
\text { Communication skills (e.g. learners talk about } \\
\text { money, its use and resources used in } \\
\text { manufacturing it; the preservation of resources), } \\
\text { etc. }\end{array}$ \\
\hline Counting & $\begin{array}{l}\text { Learning about the environment (e.g. by counting the trees in the } \\
\text { learner's surroundings) feasible. The teacher may expand the lesson } \\
\text { to focus on preservation of include trees. }\end{array}$ & $\begin{array}{l}\text { Cognitive skills (e.g. observation and counting of } \\
\text { objects in the learner's environment; and talking } \\
\text { about the value of the objects in the and the need } \\
\text { to preserve them), etc. }\end{array}$ \\
\hline $\begin{array}{l}\text { Passing of } \\
\text { time }\end{array}$ & $\begin{array}{l}\text { Learning about, in and for the environment feasible. This could be } \\
\text { done through the integration of experimentation (e.g. the teacher } \\
\text { may use a pot seed-planting experiment to demonstrate the } \\
\text { changes, such as seed germination and plant growth, that occur } \\
\text { over time). Focus could also be on the role of water and sunlight in } \\
\text { plant growth. The lesson could include a discussion on the need to } \\
\text { take care of nature. }\end{array}$ & $\begin{array}{l}\text { Cognitive skills (observation and thinking about } \\
\text { experiment outcomes), } \\
\text { Communication skills (discussion about the } \\
\text { changes in the experiment over time), } \\
\text { Physical skills (e.g. development of fine-motor } \\
\text { skills during the planting of seeds by learners), etc. }\end{array}$ \\
\hline
\end{tabular}

\section{DISCUSSION}

The findings of this study suggest that, as per the Curriculum and Assessment Policy Statement (CAPS) pursued in South African schools, each of the subjects offered in Grade R classrooms contains numerous topics that could be used to support the incorporation of EE in pedagogy. However, of the three subjects, Life Skills seems to contain more topics that could facilitate the teaching and learning of EE than English Home Language and Mathematics, respectively. Nonetheless, because the teaching approach pursued in Grade R advocates for an integration of all three subjects, this should not be a hindrance to the inclusion of EE in the classroom. For example, a lesson on Animals: birds, reptiles, dinosaurs and other wild animals (Table 2) would accommodate both Life Skills (e.g. a focus on how humans could relate with and treat animals is one essence of life skills that could be explored in the classroom) and English Home Language (e.g. a discussion on various animals would help enhance language skills in learners).

Additionally, the findings also indicate that certain topics could be integrated through the use of all three strategies conceived by Lucas (1972), i.e. education about, in and for the environment. This is feasible in topics such as; Farming: dairy, wool, fruit and vegetable and Animals: birds, reptiles, dinosaurs and other wild animals (Table 2). However, there are also several topics that could be implemented only through the use of only one strategy, i.e. education about the environment. The topic on Space and Shape (Table 3) is one of those topics that would, conceivably, focus only on education about the environment. Nonetheless, creative and highly competent teachers could be able to use all three strategies even in instances where, as this study suggests; only one EE-inclined strategy would, ordinarily, be feasible.

This study also suggests that a variety of domains could be developed through the inclusion of EE in Grade R. This is in line with what is expected of an 'ideal' preschool curriculum (Lind, 1998). Hence, each of the three tables, above, provides examples of the spheres that could be developed during the implementation of EE in Grade R. These areas of development include but are not limited to domains such as; cognition, affective, physical, and language. Accordingly, it could be argued that since it provides for the development of various areas in a learner, an EE-inclined pedagogy has the propensity to enable a holistic development in the learner and, thus it is worth undertaking.

\section{LIMITATIONS OF THE STUDY}

This research, like any other empirical inquiry, has its limitations. Owing to the dearth of literature with similar focus to this investigation, there was, virtually, no text which served as a point of reference for this researcher. Hence, this called upon the innovativeness of the inquirer. It is for this reason that the theoretical framework discussed earlier in this paper was used for grounding this research inquiry. 
The other notable limitation is methodological in nature. Two issues are worth noting in this regard. First, notwithstanding the invaluableness of abduction as a recontextualising mode of reasoning that produces knowledge and insight (Ovchinnikova, Gordon \& Hobbs, 2013; Yu, 2005), some scholars have dubbed it weak and conjectural (Plutynski, 2011; Aliseda, 2007). For this reason, some could cast doubt on any findings stemming from the application of abduction. The other notable limitation worth acknowledging evolves around the use of content analysis for research design. Potter \& Levine-Donnerstein (1999) aver that content analysis "allows for subjective interpretations" (p. 260) while Krippendorff (1980) argues that, generally, procedures used in content analysis are designed for a specific set of data, purpose or situation only. Therefore, findings emanating from content analysis are often difficult to reproduce and/or generalise. Nonetheless, these limitations do not suggest that the purpose of this study was not fulfilled. This should be discernible from the findings already presented.

\section{CONCLUSION}

This study highlights that although the South African National Curriculum and Assessment Policy Statement (CAPS) sponsors the implementation of EE, numerous challenges hamper the realisation of this ideal. However, this inquiry tried to demonstrate that these challenges are not insurmountable. It illustrates that the absence of guidelines that should assist teachers to make informed decisions on what (pedagogical content) and how (teaching approaches) to integrate EE in their lessons can, without a doubt, be overcome.

It is the view of this researcher that in order to translate the aims of the CAPS on EE into reality, it might be prudent for the South African National Department of Basic Education (DBE) to provide guidelines on the what and how of EE integration in various subjects and grades. More importantly, because of the paucity of studies, globally, that focus on the problem of this study and the fact that this investigation focused narrowly on Grade R; more in-depth research with a wider scope, which seeks to address the absence of EE-enabling guidelines in CAPS, is needed. This is necessary, especially, when one considers the fact that this problem affects all subjects and grades through the entire system of the DBE. Thus, it is the view of this researcher that this study could be used as the basis to inform this process. Furthermore, it is also the view of this researcher that since CAPS explicitly accommodates EE implementation yet, as literature indicates, the integration of EE is not on the upwards trajectory; it is necessary to conduct on-going inquiries that seek to find reasons for and solutions to this shortcoming.

Additionally, turning to the global terrain, some points are also worth noting. This paper underscored the fact that in many countries, globally, the implementation of EE is a prerogative of individual teachers. At the same time, it appears that as it is the case with South Africa; school curricula do not guide teachers on which topics to select or how to select and use them for the purposes of implementing EE. More importantly, as alluded in the preceding paragraph, this study also amplified the dearth of research that focuses on the identification of topics that could enable EE implementation in the school curriculum. Accordingly, it could be argued that this study does not only "provide insights and encouraging perspectives for practitioners struggling to implement environmental and sustainability education" Evans, et al. (2012, p. 135); but it also challenges researchers to seriously consider exploring this area of research (insertion and emphasis by this researcher) so as to contribute towards filling the void identified in this study.

\section{REFERENCES}

Aliseda, A. (2007). Abductive reasoning: Challenges ahead. Theoria, 60, $261-270$.

Anand, M., Gonzalez, A., Guichard, F., Kolasa, J \& Parrott, L (2010). Ecological systems as complex systems: Challenges for an emerging science. Diversity, 2, 395-410. https:/ / doi.org/10.3390/ d2030395

Bernstein, B. (1999). Vertical and horizontal discourse: An essay. British Journal of Sociology of Education, $20(2), 157$ 173. https:/ / doi.org/10.1080/01425699995380

Bernstein, B. (2003a). On the classification and framing of educational knowledge. In Bernstein, B., Class, codes and control, Volume I: Theoretical studies towards a sociology of language (Chapter 11, pp. 156 - 177), London: Routledge, Taylor \& Francis Group.

Bernstein, B. (2003b). Social class and pedagogical practice. In Bernstein, B., The Structuring of pedagogic discourse, Volume IV: Class, codes and control (Chapter 10, pp. 196 - 217), London: Routledge

Binstock, M. (2006). A survey of national environmental education and education for sustainable development laws and policies - lessons for Canada, Canadian institute for environmental law and policy, Toronto: Ontario

Connell, P., Shearer, A \& Tobin, T. (2006). Early years curriculum guidelines. Brisbane: The State of Queensland.

Cottrell, R. R., \& McKenzie, J. F. (2005). Health promotion and education research methods: Using the five-chapter thesis/dissertation model. Sudbury, Massachusetts: Jones and Bartlett Publishers.

Creswell, J. W. (1994). Research design: Qualitative and quantitative approaches. London: Sage Publications. 
Daymon, C., \& Holloway, I. (2011). Qualitative research methods in public relations and marketing communication (2nd Ed.), London: Routledge.

Department of Basic Education (DBE). (2011a). National curriculum statement (NSC), Curriculum and assessment policy statement (CAPS) English home language foundation phase grade $R$ - 3. Pretoria: Government Printer. Retrieved from https://www.education.gov.za/Curriculum/CurriculumAssessmentPolicyStatements(CAPS)/ CAPSFoundation/tabid/571/Default.aspx

Department of Basic Education (DBE). (2011b). National curriculum statement (NSC) Curriculum and assessment policy statement (CAPS) English mathematics foundation phase grade R. Pretoria: Government Printer. Retrieved from https://www.education.gov.za/Curriculum/CurriculumAssessmentPolicyStatements(CAPS)/CAPSFou ndation/tabid/571/Default.aspx

Department of Basic Education (DBE). (2011c). National curriculum statement (NSC) Curriculum and assessment policy statement (CAPS) English life skills foundation phase grade $R$ - 3. Pretoria: Government Printer. Retrieved from https://www.education.gov.za/Curriculum/CurriculumAssessmentPolicyStatements(CAPS)/CAPSFou ndation/tabid/571/Default.aspx

Eilam, E., \& Trop, T. (2012). Environmental attitudes and environmental behaviour: Which is the horse and which is the cart? Sustainability, 4, 2210-2246. https:// doi.org/10.3390/su4092210

Erdoğan, M., Bahar, M., Özel, R., Erdaş E., \& Uşak, M. (2012). Environmental education in 2002 and 2006: Early childhood curriculum. Educational Sciences: Theory and Practice, Special Issue, 3259-3272.

Evans, N., Whitehouse, H \& Gooch, M. (2012). Barriers, success and enabling practices of education for sustainability in Far North Queensland schools: A case study. The Journal of Environmental Education, 43(2), 121-138. https:/ / doi.org/10.1080/00958964.2011.621995

Fien, J. (2001). Education for sustainability: Reorientating Australian schools for a sustainable future, Issue 8: The Australian Conservation Foundation.

Gordon, A. M., \& Browne, K. W. (2011). Beginnings and beyond: Foundations in early childhood education (8th Ed.), Belmont, California: Wadsworth Cengage Learning.

Green, M., \& Somerville, M. (2015). Sustainable education researching practice in primary schools. Environmental Education Research, 21(6), 832-845. https:/ / doi.org/10.1080/13504622.2014.923382

Ham, S. H., \& Sewing, D. R. (1988). Barriers to environmental education. Journal of Environmental Education, 19(2), 17-24.

Ketlhoilwe, M. (2003). Environmental education policy implementation in Botswana: The role of secondary education officers and school heads. Southern African Journal of Environmental Education, 20, 75-84.

Ko, A. C., \& Lee, J. C. (2003). Teachers' perceptions of teaching environmental issues within science curriculum: A Hong Kong perspective. Journal of Science Education and Technology, 12(3), 187-204. https://doi.org/10.1023/A:1025094122118

Kopelke, D. (2012). Environmental education through listening to children. D.Ed. Thesis, Queensland, Australia: Queensland University of Technology.

Krippendorff, K. (1980). Validity in content analysis. In E. Mochmann (Ed.), Computerstrategien für die kommunikationsanalyse. Frankfurt, Germany: Campus, pp. 69 - 112.

Lane, J. F. (2006). Environmental education implementation in Wisconsin: Conceptualizations and practices (PhD Thesis), Wisconsin: University of Wisconsin-Madison.

Lassiter, D., \& Goodman, N. D. (2017). How many kinds of reasoning? Inference, probability and natural language semantics, pp. 1-23. https:/ / web.stanford.edu/ danlass/Lassiter-Goodman-reasoning.pdf

Le Grange, L. (2002). Towards a "language of probability" for environmental education in South Africa. South African Journal of Education, 22(2), 83-87.

Lind, K. K. (1998). Science in early childhood: Developing and acquiring fundamental concepts and skills. Mathematics, and Technology Education: Paper presented at the Forum on Early Childhood Science. https:/ / doi.org/10.1007/BF03400600

Lucas, A. M. (1972). Environment and environmental education: Conceptual issues and curriculum implications (PhD Thesis). Ohio: The Ohio State University.

Maharajh, L. R., Nkosi, T., \& Mkhize, M. C. (2016). Teachers' experiences of the implementation of the curriculum and assessment policy statement (CAPS) in three primary schools in KwaZulu-Natal. Africa's Public Service Delivery and Performance Review, 4(3), 371-388. https:/ / doi.org/10.4102/apsdpr.v4i3.120

Mathenjwa, J. S. (2014). The implementation of environment al education in the Ubombo circuit schools (M.Sc. Dissertation), Ongoye: University of Zululand. 
McBride, B. B., Brewer, C. A., Berkowitz, A. R., \& Borrie, W. T. (2013). Environmental literacy, ecological literacy, Ecoliteracy: What do we mean and how did we get here? Ecosphere, 4(5), 1-20. Article 67. Retrieved from www.esajournals.org

Mokhele, M. L. (2011). Integrated environmental teaching in South Africa: An impossible dream? Perspectives in Education, 29(4), 78-86.

Motshegoa, M. E. (2006). The policy and practice of environmental education in South African schools (M.Ed. Dissertation), Pretoria: University of South Africa.

Mwendwa, B. (2017). Learning for sustainable development: Integrated environmental education in the curriculum of ordinary secondary schools in Tanzania. Journal of Sustainable Education, 12, 21.

Norris, E. I. (2016). Actualizing the goals of environmental education in Nigeria. Journal of Education and Practice, $7(8), 1-5$.

Nsubuga, Y. (2008). A Bernstein analysis of the integration of natural resource management in the curriculum of a rural disadvantaged school. Southern African Journal of Environmental Education, 25, 98-112.

Ovchinnikova, E., Gordon, A. S., \& Hobbs, J. (2013). Abduction for discourse interpretation: A probabilistic framework. In Proceedings of the joint symposium on semantic processing, pp. 42-50.

Plutynski, A. (2011). Four problems of abduction: A brief history. The Journal of the International Society for the History of Philosophy of Science, 1, 1-22. https:/ / doi.org/10.1086/660746

Potter, W. J., \& Levine-Donnerstein, D. (1999). Rethinking validity and reliability in content analysis. Journal of Applied Communication Research, 27(3), 258-285. https:/ / doi.org/10.1080/00909889909365539

Ralph, M., \& Stubbs, W. (2014). Integrating environmental sustainability into universities. Higher Education, 67, 7190. https:/ / doi.org/10.1007/s10734-013-9641-9

Roth, C. E. (1992). Environmental Literacy: Its Roots, Evolution and Directions in the 1990s, Columbus, OH: ERIC Clearinghouse for Science, Mathematics and Environmental Education.

Sappleton, N. (2013). Advancing research methods with new technologies. Hershey, Pennsylvania: Information Science References. https://doi.org/10.4018/978-1-4666-3918-8

Schudel, I., Le Roux, C., Lotz-Sisitka, H., Loubser, C., O’Donoghue, R., \& Shallcross, T. (2008). Contextualising learning in advanced certificate in education (environment education) courses: Synthesising contexts and experiences. South Africa Journal of Education, 28, 543-559.

Songqwaru, N. Z. (2012). Supporting environment and sustainability knowledge in the grade 10 life sciences curriculum and assessment policy context: A case study of the fundisa for change teacher education and development programme pilot project, MEd Thesis, Grahamstown: Rhodes University.

Srbinovski, M., Erdoğan, M., \& Ismaila, M. (2010). Environmental literacy in the science education curriculum in Macedonia and Turkey. Procedia-Social and Behavioural Sciences, 2, 4528-4532. https:// doi.org/10.1016/j.sbspro.2010.03.725

Stokes, E., Edge, A., \& West, A. (2001). Final report: Environmental education in the education system of the European Union. European Commission: Brussels.

Svenning, J. (2001). Abduction as a methodological approach to the study of spoken interaction. Norskrift, 103, 122.

Yu, C. H. (2005). Abduction, deduction and induction: Their implications to qualitative methods, pp. 1 - 32. Retrieved from http:/ / creative-wisdom.com/teaching/WBI/abduction5.pdf

\section{http://www.ejmste.com}

